\title{
Manevi Değerlerin Farklılıklar Yönetimi Üzerindeki Etkisi *
}

\author{
The effect of spiritual values on diversity management
}

\author{
Merve GÜLTEKİN 1 a \\ Hüner ŞENCAN ${ }^{2}$ \\ 1 İstanbul Ticaret Üniversitesi, Sosyal Bilimler Enstitüsü, İstanbul. merveozabus@hotmail.com \\ 2 İstanbul Ticaret Üniversitesi, İşletme Fakültesi, İstanbul. huners@gmail.com \\ a Yazışılan yazar/Corresponding author
}

\section{Özet}

Globalleşen iş dünyasında farklılıkların bir sorun değil aksine bir zenginlik ve kazanç olduğu düşüncesi kurumlarda yerleşmiştir. Küçük veya büyük ölçekli tüm işletmelerin bu durumdan faydalanma isteği bu konunun araştırılmasını gündeme getirmiştir. Insanların sahip olduğu manevi değerler de her birey için özel ve biriciktir. Manevi değerlerin de farklılık gösterdiği örgütlerde farklıliklarm yönetimi uygulamalarında bu manevi değerlerde etkilidir. Yapılan bu çalışmada manevi değerlerin farklılıkların yönetimi üzerindeki etkisi incelenmiştir. Bu çalışma için Farklılıkların Yönetimi Ölçeği ve Manevi Değerler Ölçeği kullanılmıştır. Çalışma sonuçları incelendiğinde manevi değerlerdeki artışın çalışanların farklılıkların yönetimi algısını arttırdı ̆̆g tespit edilmiştir.

Anahtar kelimeler: Farklılıklar yönetimi ölçeŏi, Manevi değerler ölçeği, Hizmet sektörü, Demografik değişkenler

JEL kodları: M10, M12.

\begin{abstract}
The idea that there is a wealth and profit in the globalized business world rather than the appropriate ones is located in the institutions. The desire of all small or large enterprises to benefit from this situation has raised the investigation of this issue. The spiritual values of people are special and unique for each individual. It is effective in the management of the differences in organizations in which spiritual values vary. In this study, the effect of spiritual values on the management of differences is examined. Diverstiy Management Scale and Spiritual Values Scale were used for this study. When the results of the study were examined, it was found that the increase in the spiritual values increased the perception of the management of the employees.
\end{abstract}

Keywords: Differences Management Scale, Scale of Spiritual Values, Service industry, Demographic variables

JEL codes: M10, M12.

\footnotetext{
* Bu çalışma Merve Gültekin'e ait “Manevi Değerlerin Farklılıklar Yönetimi Üzerindeki Etkisi” adlı yüksek lisans tezinden türetilmiştir.
} 


\section{GİRIŞ}

Her bireyin biricik olması kendisini diğer bireylerden farklı bir varlık haline getirmektedir. Bireylerin birlikte yaşadığı ve çalıştığı ortamlarda farklılıkların olması kaçınılmazdır. Bu farklılıkların çalışma ortamında yönetilebilmesi çatışmalardan kaçınılması, uyumsuzlukların giderilmesi ve ortaya çıkabilecek diğer problemlerin önüne geçilmesi için son derece önemlidir.

Farklılıkların yönetimi belirli kurallar, yöntemler ve prosedürler ile yapılabilen bir uygulama değildir. Bu nedenle farklılıkların yönetimi üzerinde etkisi olan bazı demografik değişkenleri ve bireylere özel olan manevi değerleri de araştırmak gerekmektedir.

Bu çalışmanın amacı manevi değerlerin farklılıklar yönetimi üzerindeki etkisinin ne olduğunu ve demografik değişkenlerin farklılıkların yönetiminde ne derece önemli olduğunu tespit etmektir.

“Manevi Değerlerin Farklılıklar Yönetimi Üzerindeki Etkisi” konulu çalışma hizmet sektörü esas alınarak yapılmış bir vaka araştırmasıdır. Araştırma bir kamu kuruluşunda yapıldığı için toplumun her kesiminden insan araştırmaya dahil edilmiştir. Araştırmanın konusu gereği manevi değerlerden, farklılıklar ve farklılıkların yönetiminden bahsetmek gerekir.

Manevi değerlerin neler olduğunu anlayabilmek için manevi kavramından yola çıkmak gerekir. Türk Dil Kurumu sözlügüne göre manevi kavramı: "görülmeyen, duyularla sezilebilen, soyut, ruhani, tinsel, maddi karşıtı" şeklinde ifade edilmektedir (Türk Dil Kurumu, 2018). Buradan yola çıkarak manevi değerler soyut, ruhani ve maddi olmayan değerlerdir. Manevi Değerler Ölçeği çalışmada üç alt boyutla işlenmiştir. Anlamlılık, düşüncelilik ve güvende olma hissi boyutları çalışma içerisinde alt maddeleri ile birlikte kullanılmıştır.

Farklılıkların yönetimini anlayabilmek için farklılık kavramından yola çıkmak gerekir. Farklılık kavramı Türk Dil Kurumu sözlüğünde yer aldığ 1 şekliyle "Farklı olma durumu, ayrımlılık, başkalık" (Türk Dil Kurumu, 2018) olarak tanımlanmaktadır. Farklılıkların yönetimi ise kurumların çalışanları arasındaki farklılıklara göstermiş oldukları tutum ve davranışlardır. Bu tutum ve davranışlar çalışanlar arasındaki farklılıkların çatışmalara neden olmasını önlemeye yöneliktir. Bu durum çalışanlar arasında uyum ve iş birliğini teşvik edicidir. Kurumda yönetici olan kişi örgütteki her çalışana aynı seviyede yaklaşıp ve farklılıkları doğal ve sosyal gerçeklikle yansıttığında çalışma uyumunun arttığı ve çatışmaların azaldığı, kurum içinde adalet ortamının çalışanlar tarafından da algılandığı görülür. Farklılıklar Yönetimi Ölçeği çalışmada üç alt boyutla incelenmiştir. Bunlar bireysel tutum ve davranışlar boyutu, örgütsel değerler ve normlar boyutu ve yönetsel uygulamalar ve politikalar boyutudur.

İnsan faktörünün bu denli önemli olduğu günümüzde işletmeler uzun soluklu hayatta kalabilmek için yeni yönetim alanlarına ihtiyaç duymaktadırlar. Farklılıkların yönetilebilmesi için örgüt çalışanlarının demografik özelliklerinin yanı sıra manevi olarak da kendilerini tanımladıkları soyut alanları da göz ardı etmemek gerekmektedir. Kişilerin inandıkları ve değer verdikleri şeyler büyük bir önem taşımaktadır. Bu inandıkları ve değer verdikleri tüm unsurlar çalışanların maneviyatını oluşturur. Tüm çalışanlar kendi manevi değerleri ışı̆̆ında 
farklılıklara çeşitli yaklaşımlar gösterir. Gösterdikleri yaklaşımlar da farklılıklar yönetimi alanında en önemli zenginliktir.

$\mathrm{Bu}$ araştırma hizmet sektöründe yapılmış olup farklı sektörler içinde farklı sonuçlar elde edilebilir. Araştırma farklılıklar yönetimi açısından olumlu anlamda katkı niteliği taşımaktadır.

\section{LITERATÜR}

\subsection{Manevi Değerler}

İnsan doğası gereği beden ve ruhtan oluşan bir öze sahiptir. Bu özün doğasında da maneviyat yer almaktadır. Hayatı anlamaya, başkalarıyla güven çatısı altında bir ilişki kurmaya ve sorgulayıp düşünmeye iten maneviyat, yukarıda da belirtildiği şekliyle kişinin doğuştan gelen bir parçasıdır.

Manevi değerlerin yeterince anlaşılabilmesi için manevi kelimesinin tanımlamasını iyi bir şekilde analiz etmek gerekmektedir. Çeşitli kaynaklarda yer alan tanımlamalarda uzlaşma yoktur ve birçok tanım yer almaktadır. Avrupa ve Amerika'da da son zamanlarda gündemde olan bu kavramlar tanımlanma sürecindedir. Türk Dil Kurumu sözlüğüne göre manevi kavramı: "görülmeyen, duyularla sezilebilen, soyut, ruhani, tinsel, maddi karşıtı" şeklinde ifade edilmektedir (Türk Dil Kurumu, 2018). Manevi sözcüğü mana kökünden türemiştir. Mana en basit ve anlaşılır haliyle sözle anlatılmak istenen şey şeklinde tanımlanabilir. Maksatları beyan etmek üzere başvurulan sözcükler ve bu sözcüklerin meydana getirdiği cümleler, belirli bir veya birden çok manayı ifade etmek için kullanılabilir (Kahveci, 2009: 186).

Maneviyat için ise çeşitli tanımlamalar mevcuttur. Manevi şeyler, madde ile alakalı olmayan; düşünce ve zihinle ilgili olan (Topsakal ve Çetin, 1996: 1898), maddi olmayan, içsel olan, kişinin iç dünyasıyla ilgili olan şeyler olarak tanımlanabilmektedir (Püsküllüoğlu, 2004: 657). Maneviyat kavramı ile ilgili bir diğer tanım ise şu şekildedir: Madde ve cisimle alakası bulunmayan, ruh ve mana ile ilgili olan hususlar, manevi şeyler-çeşitli güçlükler tehlikeler karşısında inanç ve ahlaki değerlere bağlllıktan doğan dayanma gücü, ruh kuvveti, moraldir (Ayverdi, 2005: 1931).

Benliğin ve kişiliğin gelişimi ve anlam arayışı gibi konularla ilişkili olan maneviyat, kişiye özgüdür. Bu nedenle şahsi ve bireysel bir konudur. Duygularımız ve tecrübelerimiz bir sosyal çevrenin içerisinde şekillenirler. Dolayısıyla deneyimlenen olaylar ve yaşanmışlıklar yadsınamaz. Bu açıdan bakıldığında kişilerin manevi yönleri ya güçlenir ya da güçlenemez. İnsanların dili, yaşadıkları yer ya da yerler, yaşama biçimleri, hayatı algılayışları, kültürleri vb. unsurlar manevi yönlerine ve dolayısıyla değerlerine de etki ederler. Buradaki maneviyat bireysel olmakla beraber sosyal çevrenin içerisinde farklı bir bakış açısı kazanır. Kişiler kendi dışında manevi olarak düşünmesi gereken şeylerle karşılaşabilirler.

Bireylerin manevi yönlerine ve değerlerine etki eden bir diğer unsur ise çalışma ortamıdır. İş hayatında farklı zamanlarda karşılaşılan farklı zorluklar iş görene bir tecrübe kazandırır. Kazanılmış olan bu tecrübe bireyin manevi yönünü güçlendirirken sahip olduğu değerlere yenilerini katabilir. Bu ilişki çift taraflı olarak yorumlanabilir. Çalışma ortamının bireyin manevi değerlerine katkıda bulunmasının yanı sıra birey sahip olduğu manevi değerleri ile çalışma ortamına katkıda bulunabilir. Manevi değerleri güçlü olan bir iş gören çalıştığı kurum için her zaman en iyisini, en doğrusunu yapmayı kendine amaç edinir. Çalışma ortamında ki 
iş arkadaşlarıyla olan ilişkisini doğru ve sağlam temeller üzerine kurabilir ve böylece çalışma ortamında takım ruhunu tam anlamıyla oluşturabilir.

Bir şeye inanıp inanmamak insanların iradesine kalmıştır. Ruh ve bedenin tabiatı olan maneviyat yönü hakikati aramak ya da bulmak isteyebilir. Bir insan Allah'a inanmamayı tercih ederse bu hakikati bulmak için olanaklarını yok etmek istediği anlamına gelmez. Çünkü en başta denildiği gibi inanıp inanmamak konusunda insanlar özgürdür. İnanmamayı tercih eden insanlar için hakikati bulma arzusu son bulmuştur denemez. İnanmak sonradan kazanılan veya benimsenen bir kavramdır. Ancak insan her zaman doğası gereği manevi olarak beslenmek isteyebilir.

Horozcu (2010) Sübjektif olarak nitelendirdiği çalışmasında dindarlık ve maneviyatın sağlık üzerindeki etkisinden söz etmektedir. Çalışmasının sonuç bölümünde yapılan araştırmalar ve önemli psikologların görüşleri incelenmiş, maneviyatın ve dindar yaşantının kişiler üzerinde ruhsal ve fiziksel sağlıklarında önemli etkilerinin olduğu ve bireyleri olumlu etkilediği tespitinde bulunulmaktadır. Buradan hareketle hayatın bir anlam ve gayesi olduğundan yola çıarak ölümden sonraki hayatında kişiye ruhsal bir doyum sağladığı ve bedensel problemlere bu şekilde karşı koyduğu tespitine de varılmıştır (Horozcu, 2010: 236).

Din ve maneviyat karşılaştırmasının birleşme ve ayrılma noktaları üzerine kaleme alınan makalede, din ve maneviyat kavramlarının temel seviyede incelendiği ve bu iki kavramın ayrılıp farklılaştığı noktaların tespit edildiği çalışma yapılmıştır. Genel görünüme ve analizlere 1şık tutan çalışma maneviyatın ya da dindarlığın birbirlerine örülü olduğunu diğer yandan da bu terimlerin bireysel, kurumsal, iyi ya da kötü olarak ayrıştırmanın basite kaçmak olarak değil aksine karmaşıklığı azaltmak adına kabul görmesini öne sürmüşlerdir (Kimter, 2013: 110).

Rio ve White'ın (2016) hilomorfik bir bakış açısıyla yazdıkları maneviyatı ve dindarlığı ayırmak adlı çalışmasında maneviyat ve dindarlığın ayrı düşünülmesi gerektiği düşüncesini savunmuşlardır. Maneviyatın türlerine göre sınıflandırılmasının ve farklı manevi kimliklerin kabul edilmesi görüşündelerdir. Maneviyatı her bireye özgü olduğunu ve bir varoluş ilkesi olarak kişinin hayata karşı tutumunu sergilendiğini çalışma boyunca değinmişlerdir. Bütün bunlar 1şığında kurumsal ve ampirik yayınların, çalışmada savunulan bireylerin insan olmalarının gerektirdiği manevi olma durumu desteklenmiştir. Kişilerin inanç toplulukları oluşturmalarının ve dini sistemler içerisinde olmaları maneviyatın bünyesinden aldıklarını yinelemişlerdir. Son olarak da hilomorfik maneviyat tutumunu geliştirmek için ve literatüre katkı sağlayacak bazı stratejiler önermişlerdir (Rio ve White, 2016: 104-107).

\subsection{Manevi Değerlerin Boyutları}

$\mathrm{Bu}$ araştırmada manevi değerlerin üç alt boyutu yer almaktadır. Bunlar anlamlılık boyutu, düşüncelilik boyutu ve güvende olma hissi boyutudur.

\subsubsection{Anlamlılık Boyutu}

Anlamlılık bütünlük duygusunun motivasyonel ögesini oluşturmakta ve birinin yaşamındaki olayları ya da ortaya çıkan olumsuzluklara meydan okuma ya da okumamaya ilişkin olarak ne derece anlamlı gördüğüne ilişkin algısını ifade etmektedir (Çeçen, 2008: 20). Anlamlılık kişinin yaşamsal doyumunu tamamlamaya katkı sağlayan bir boyuttur. Kişi kendini 
yükseltmeye ve geliştirmeye çalışır. Bu sırada çevresinde olan gördüğü ya da görmediği şeylere karşı arayış içindedir. En önemli noktası hayatı anlamaya çalışmaktır. Hayatı anlamaya çalışmak zihni açan ve kendisini de anlamasına yardımcı olan bir süreçtir. Kişi bireysel bütünlügüunü ve benlik saygısını oluştururken de henüz çok küçük yaşlardan itibaren kendi için anlamlı olan birçok değer oluşturur. Oluşturulan bu değerler ilerleyen yaşamında hayatı anlama çabası hususunda da kişiye yol gösterir. Bir diğer tanımda ise anlamlılık bireye, kendisini ve çevresini tanıtarak kimlik kazandırmaya yardımcı olan bir kavramdır (Erdem ve Kesgin, 2017: 128). Marcia (1994)'a göre ise kimlik; sosyal bağlam içerisinde bireyin kendisindeki ve başkalarındaki anlamlılık duygusudur (Demirkapı, 2013: 40).

Anlamlılık boyutunda bireylerin anlam arayışı içerisinde olması manevi değerlerin diğer boyutları açısından besleyici bir özellik göstermektedir. Çünkü bireyler hayatını anlamlandırmaya çalışırken diğer boyutları oluşturan düşüncelilik ve güvende olma hissini önemserler. Bireyler hayatın anlamlı olabilmesi için önce güvende olma ve sonrasında düşünceli davranmanın gerekliliğinin farkındadırlar.

\subsubsection{Düşüncelilik Boyutu}

Bireyler kendilerini daha iyi hissetmek, yaşadıkları aile ve toplum içinde daha mutlu olmak, sevilmek ve saygı görmek ve çalıştıkları kurumlarda örgüt içinde çeşitli çatışmalardan kaçınmak ve sıkıntı yaşamamak için düşünceli olmaları gerekmektedir. Düşüncelilik boyutu empati yapmayı gerektirir. Empati bir bireyin kendisini bir başkasının yerine koyarak onun gibi hissetmeye ve düşünmeye çalışması olarak tanımlanmaktadır (Ersoy ve Köşger, 2016: 2). Bireyler arası iletişimde de oldukça önemli olan empati yapmak duygu ve düşüncelerin doğru bir şekilde algılanmasını sağlamaktadır. Düşüncelilik diğer bireylerle sosyal ilişkilerde anlayışlı olmayı gerektirirken anlayış diğer bireylere karşı açık ve duyarlı olmayı beraberinde getirir. Sabır, nezaket, hoşgörü ve düşüncelilik gibi faktörler de anlayışlı olmanın temelini oluşturmaktadır (Deniz vd. 2012: 428).

Düşüncelilik kavramı bireysel, aile-toplum ve çalışma hayatı içerisinde olmak üzere üç ana başlık altında incelemek mümkündür. Bireysel düşüncelilik bireyin kendini geliştirmesinde son derece önemli bir faktördür. Kişi gelişime açılık açısından değerlendirildiğinde en etkili faktörler içerisinde başkalarının fikirlerine açıklık, yaratıcılık, hayal gücü, düşüncelilik, çeşitlilik vb. bulunmaktadır (Tozkoparan, 2013: 199). Aile ve toplum içerisinde olması gereken düşüncelilik ise aile bireylerini ve aynı toplumda yaşayan bireylerin birbirleriyle daha iyi geçinmelerini, daha kolay anlaşabilmelerini, fikir ve düşünce uyuşmazlıklarında çatışmalar yaşanmadan çözüm üretilmesine olanak sağlar. Birey çalıştığ 1 kurumlar içerisinde diğer çalışma arkadaşlarıyla birlikte bir takım oluşturmaktadır. Bu takım oluşumu içerisinde uyumun yakalanması son derece önemlidir. Bu uyuma yatkınlık gösterebilen bireyler için meslektaşlarıyla verimli bir ilişki kurabilen ve onlara karşı düşünceli yaklaşım gösterebilen bireyler şeklinde bir tanım yapılabilmektedir (Gürel, 2006: 137). Bu takım ruhu içerisinde bireyler birbirlerine karşılıklı olarak destek olabilmek için nazik ve düşünceli davranışlar sergilemelidirler. Bu takım veya örgüt içerisinde çalışan her birey karşısındaki bireyin kendisine karşı düşünceli ve nazik olacağı inancına sahip olduğu zaman kurum içinde pozitif sonuçlar sağlanabilir. 


\subsubsection{Güvende Olma Hissi Boyutu}

Sağlığın TDK'de yer alan tanımı bireyin fiziksel, sosyal ve ruhsal yönden tam bir iyilik durumunda olması, vücut esenliği, esenlik, sıhhat, afiyet şeklindedir (Türk Dil Kurumu, 2018). Biyolojik olarak bozulmuş olan sağlığın yerine getirilmesi için nasıl ki tedavi ve ilaç arayışına giriliyor ise, ruh sağlığın teminatı için de insan güvende olma hissine muhtaçtır. İnsan kendini güvende hissettiği zaman her şeyin yolunda gittiğini düşünür (Tarhan, 2012). İnsanlar arasındaki ilişkilerde en temel duygu güvendir. Birey güven duyduğu kişilere karşı barış ve sevinç içinde olur ve saygı duyar. Güven duygusu insanların içinde bulunan boşluğu doldurur. İnsanlar bu hisse hem tutunmak hem de teslim olmak isterler.

Güvende olma hissi bireyin kendi içinde, toplum içinde ve örgüt içinde olarak ayrı ayrı incelenebilir. İlk olarak bireyin kendi içinde güvende olduğu hissinin oluşması bireyin iç dünyasında mutlu olmasını sağlamaktadır. Güvende olduğunu hisseden, düşünen kişi içinde derin bir barış hisseder. Yaşadığı hayat içinde karşılaşabileceği sorunlara karşı kendinden emin bir şekilde yaşar. Bu sorunlardan herhangi biriyle karşılaştığında ise daha soğukkanlı ve pratik şekilde çözümler üretebilir. Toplum içerisinde güvende olma hissi ise bireyin yaşadığ1 toplumdan zarar görmeyeceği, kendisini o toplum içinde mutlu, huzurlu ve barış dolu hissedebilmesidir. Birey toplum içinde yaşarken dışarıdan gelecek birçok tehlikeye ve tehdide açıktır. İşte gelebilecek bu tehdit ve tehlikelerin toplumun yani birlikte yaşadığ varlığ sayesinde engellenebileceği düşüncesi bireyin toplum içinde güvende olma hissini tanımlamaktadır. Örgüt içinde güvende olma hissi ise bireyin çalıştığı kurumla alakalıdır. Birey çalışma ortamında kendini ne kadar güvende hissederse o kadar verimli olur. Sürekli işini kaybetme kaygısı, ücretini alamama endişesi, iş arkadaşlarıyla anlaşamama vb. korkulara sahip çalışanlar örgüt içinde kendini güvende hissedemez ve çalışma hayatında tam bir mutsuzluk hakim olur. Bunun önüne geçilebilmesi için iş gören çalıştığı ortamda, örgüt içinde kendini güvende hissetmelidir. Bu güven hissinin oluşması neticesinde işsiz kalma, maaşını alamama, arkadaşlarıyla anlaşamama gibi korkularını yenerek kurum için daha verimli işler yapan bir çalışan haline gelebilir.

\subsection{Farklılıklar Yönetimi}

Dünya üzerinde hemen her örgütün temel bileşeni insan değişkeni olduğundan örgütsel araştırmalar yapılırken insan unsurunu göz ardı etmek mümkün değildir. Ancak insan her anlamda değişken bir varlıktır. Bu değişkenlik durumu ise farklılık kavramını ortaya çıarmaktadır (Özan ve Polat, 2013: 55-56). İnsan farklılıkları, yaşamın tüm alanlarında yönetilmesi gereken bir olgu olarak değerlendirilmekte ve örgütsel yaşam içinde daha da önem kazanmaktadır. Bu doğrultuda işletmecilik ve yönetim alanında "farklılıkların yönetimi" adıyla anılan bir yönetim paradigması çıkmaktadır (Sürgevil ve Budak, 2008: 66).

Farklılık birçok kişi tarafından farklı bakış açılarıyla değerlendirilip tanımlanan ve farklı tanımlamalara sahip bir kavramdır. Cross vd. (1994) farklılığı; ırkçılık, cinsiyet ayrımcılığı, heteroseksizm, sınıfçılık, engellilere yönelik ayrımcılık konuları ve birey, kimlik grubu ve sistem düzeyindeki diğer ayrımcılık türleri ile ilgili bir kavram olarak tanımlamaktadır (Okat, 2010: 9). Farklılıkların yönetimi, iş gücünden doğan farklılıkların yarattığ1 olumsuzluğun örgüt ortamında giderilmesi, toplumsal farklılıkları örgüt içine yansıtan, çalışanları anlayan, onlara kendilerini kıymetli ve biricik hissettirmesi gereken aynı zamanda onlara değer veren ve farklı tüm niteliklerine saygı duyulan örgüt yaşantısını sunabilmek için daima var olması 
gereken bir yönetsel süreçtir (Yetgin, 2016: 7-8). Gagnon ve Cornelius'a (2002) göre, çalışma yaşamında eşitliği sağlamayı amaçlayan farklılıklar yönetimi, eşitlikteki odak noktası olarak benzerlik kavramı yerine farklılık kavramını kullanması ile farkını geniş ölçüde ortaya koymaktadır. Onlara göre farklılıkların yönetimi, bireysel düzeydeki farklılıklara saygı gösterme ve baskın olmayan ya da aynı oranda temsil edilmeyen sosyal grupların farklılıklarına "farklılıklara yönelik eşitlik" anlayışı ile değer verme düşüncesine odaklanmaktadır (Bassett-Jones vd. 2007: 60).

Farklılıklar yönetimi boyutlarına geçilmeden önce çalışanların cinsiyet, yaş, statü, kıdem ve eğitim durumları gibi demografik değişkenlerinden de bahsedilmesi gerekmektedir. Farklılıkların yönetiminde "cinsiyet" farklılıkları önemli konulardan biridir. Kadınların iş hayatına girmesiyle çalışma kademelerinde kendilerine yer edinme istekleri en doğal hakları olduğu için hak ettikleri veya arzu ettikleri kademelere yerleşebilmeleri açısından da farklılıkların yönetiminin doğru bir şekilde yapılması son derece önemlidir. Bir diğer demografik değişken ise yaştır. Çalışma hayatında ilerlemiş yaşın en önemli getirisi deneyimdir. Yaş ilerledikçe kişilerin kıdemlerinin artabileceğinden iş tatminleri çoğalacaktır. Farklılıkların yönetimi açısından bakıldığında ise farklı yaşlara sahip olan çalışanlardan daha yüksek verim elde etmek asıl amaçtır. Farklılıkların yönetiminde bir diğer önemli unsur eğitimdir. Günümüzde bilgi ve teknolojideki gelişme ve değişmeler kurum içi eğitimlerin insan kaynakları tarafından verimliklerini arttırması gerektiği gerçeğini ortaya koyuyor. Hem personelin hem de yöneticilerin eğitilmesi eğitimdeki açığı gidermek adına oldukça önemlidir. İşletmelerdeki statüler, yani yönetici olanlar ve olmayanlar farklılıkların yönetimi açısından önem arz eden konulardandır. Sorumluluk daha çok yöneticiler üzerindedir. Kıdem çalışanların kurumdaki çalışma süreleri olarak tanımlanabilir. Zaman içerisinde artış gösteren bir kavramdır. Belirli bir kıdeme sahip çalışanlar kurumu daha iyi tanıyabilmektedirler.

Tozkoparan ve Vatansever'in (2011) “Farklılıkların Yönetimi: İnsan Kaynakları Yöneticilerinin Farklılık Algısı Üzerine Bir Odak Grup Çalışması" adlı araştırmasında insan kaynakları yöneticilerinin farklılık algılarının çalıştıkları işletmenin faaliyette bulunduğu sektöre, örgüt yapısına ve kültürüne, işletmenin faaliyet alanına, örgütün ihtiyaçlarına ve çalışan yapısı ile çeşitliliğine bağlı olarak farklılık gösterdiği söylenmektedir. Ayrıca Türkiye'de kendinden farklı olana tahammülün sinırlı düzeyde olduğu belirtilmektedir (Tozkoparan ve Vatansever, 2011: 106).

Sürgevil ve Budak (2008) "İşletmelerin Farklılıkların Yönetimi Anlayışına Yaklaşım Tarzlarının Saptanmasına Yönelik Bir Araştırma" isimli çalışmasında farklılıkların yönetimi ile ilgili işletmelerin ancak belirli bir düzeyde sınırlı kalacak şekilde uygulamalar gerçekleştirdiğini, bunların yeterli sayılamayacağını ve uygulamada gelişmeye muhtaç alanların olduğunu söylemektedirler (Sürgevil ve Budak, 2008: 89).

Memduhoğlu (2011) “Liselerde Farklılıkların Yönetimi: Bireysel Tutumlar, Örgütsel Değerler ve Yönetsel Politikalar" isimli araştırmasında yönetici ve öğretmenlerin farklılıklar konusunda genelde olumlu görüşlere sahip oldukları, farklılıkları bir zenginlik olarak gördükleri sonucuna vardığını belirtmektedir (Memduhoğlu, 2011: 49). 


\subsection{Farklılıklar Yönetimi Boyutları}

\subsubsection{Bireysel Tutum ve Davranışlar Boyutu}

Araştırma kapsamı içerisinde farklılıkların yönetimi boyutlarından bireysel tutum ve davranışlar boyutunun temelinde sosyal ve kültürel farklılıklar yer almaktadır. Kişinin inançları, değerleri, tutumları, algısı, örf ve adetleri, bireysel tutum ve davranışlar boyutunun alt yapısını oluşturmaktadır. Bu alt yapının oluşmasında inanç sistemleri, etnik kökenler, yöresel etkenler ve başka toplumlarla etkileşimler rol oynar ve kültürün paylaşıldığı fiziki çevre o kültürün izlerini taşır (Direk, 2006: 106). Davranış bilimciler ve sosyal psikologlar değerlerin bir yandan bireysel tutum ve davranışları ve bilişsel süreçleri etkilediğini; diğer yandan toplumun kültürel kalıplarıyla etkileşimde bulunduğunu ve onları yansıttığını kabul etmektedirler (Dilmaç vd. 2008: 70).

Tutum, bir bireye atfedilen ve onun bir psikolojik obje ile ilgili düşünce, duygu ve davranışlarını düzenli bir biçimde oluşturan bir eğilimdir (Kağıtçıbaşı, 1988: 84). Tutumlar hem davranışların oluşmasına etki eder hem de değişime karşı direnç gösterirler. Tutumların oluşmasında aynı tür deneyimlerin artması ve iyi kötü ayrımı yapılmaksızın tüm davranışların alınması tutumların oluşmasını etkiler. Bireylerin gereksinimleri, kitle iletişim araçları da etki eden faktörler arasındadır. Tutumların oluşumuna etki eden diğer etkenler ise genetik faktörler, fizyolojik etkenler, kişilik, toplumsallaşma süreci (sosyalizasyon), grup üyeliği ve grup normu da yer almaktadır. Bir konuya karşı olumlu ve olumsuz verilen tepkilerden oluşan tutumlar bireyin duygu, düşünce ve davranışlarının süzgecinden geçmektedir. Tutumun davranış faktörü, kişinin bir harekete eğiliminin olması halidir. Kişinin inanç ve bilgileri sonucunda ortaya çıkan yargısı onu bir objeye karşı olumlu veya olumsuz harekete eğimli hale getirecektir (Sardarov, 2012: 5). Bireylerin tutumları davranışlarını ortaya koymaktadir.

Bu bölümde yer alan bütün tanımlar farklılıkların yönetimi konusunda her bireyin yaklaşımının çok farklı olabileceğini göstermektedir. Çünkü her çalışanın yukarıda bahsedildiği şekilde farklı bireysel tutum ve davranışları vardır. Bu yüzden farklılıkların yönetimi boyutlarından biri olan bireysel tutum ve davranışlar boyutu bu çalışmada önemli bir yer teşkil etmektedir.

\subsection{2. Örgütsel Değerler ve Normlar Boyutu}

Norm; sosyoloji, matematik, hukuk, felsefe disiplinleri ile bu disiplinlerin türevi olan alt disiplinlerde kullanım ve anlam alanı olan bir kavramdır. Normlar türleri açısından incelendiğinde hukuksal normlar, töresel normlar, dinsel normlar ve ahlaksal normlar şeklinde sınıflandırılabilir. Hukuksal normlar hukuk kuralları olarak da bilinen yaptırımları olan norm tipidir. Örneğin hukuk içerisinde yer alan emirler ve yasaklar hukuksal normlardır. Töresel normlar ise gelenek, görenek, örf, adet, anane olarak da tanımlanabilmektedir. Töresel normlar toplumlar için son derece önem arz etmektedir. Toplumlar arasında bazı farklılıklar göstermektedir. Dinsel normlar hakkında kesin net bir tanım olmasa da kaynağının ilahi bir güç olduğu kabul edilmektedir. Bu normlar manevidir.

Değer kavramının tanımlanması bireyler ve örgütler için farklı şekillerde yapılabilir. Kluckhohn değeri, "bir grubun niteliğini ya da bir bireyin özelliğini örtülü ya da açık olarak 
belirten, eylemin tarzları, araçları ve amaçları arasından tercih yapmayı etkileyen, arzu edilebilen bir kavram" olarak tanımlamaktadır (Vurgun ve Öztop, 2011: 219)

Kişilerin sahip olduğu bireysel değerlerin yanı sıra çalıştıkları kurumlardaki örgütsel değerler de bu kurumlar için çok önemlidir. Değer sistemi, örgüt kültürünün kilit unsurudur. Örgütün üyeleri için iyi ve kötüyü, istenip istenmeyeni, yapılması ve yapılmaması gerekenleri belirler ve örgütsel davranışların temelini oluşturur (Bütüner, 2011: 48). Literatürde bireysel değerlerin örgütsel değerlerle uyumlu olmasının çalışanların iş davranışları üzerinde etkili olacağına işaret edilmektedir. Çalışanların örgütsel bağlılık duygularının ve iş performanslarının geliştirilmesi için birey-örgüt değerlerinin uyumunun yüksek olması arzu edilmektedir (Kılıç, 2010: 21). Kurumda çalışan personellerin davranışlarını rahatlıkla sergileyebilmeleri, birbirlerinin farklı yaşam biçimlerine saygı duymaları, farklı görüşleri anlayışla karşılamaları ve bütün bunların sonucunda birbirleriyle rahatlıkla iletişim kurmaları ya da kuramamaları örgütsel değerler ve normların işletme içerisinde ne kadar oturduğuna bağlıdır.

\subsubsection{Yönetsel Uygulamalar ve Politikalar Boyutu}

Kurumlardaki mevcut örgütsel kültürün şekillenmesinde yönetsel uygulamaların etkisi önemlidir. Yönetsel uygulamalar aynı zamanda çalışanların verimliliğini arttırır. Çalışanlardan elde edilen faydanın artması neticesinde kurumların elde ettiği bu avantaj yönetsel uygulamalar ve politikaların bir getirisidir. Bu nedenle kurumlarda görev alan yöneticilerden beklenen çalışma alanına ve çalışanlara uygun olan yönetsel uygulamalar ve politikalar oluşturmalarıdır. Yönetsel uygulamalar ve politikalar boyutunda daha fazla ön plana çıkan çalışanlar yönetici sınıfı olsa da yönetici olmayan çalışanların da bu boyutta üzerine düşen bazı sorumlulukları vardır. Yöneticilerin çalışanlar için belirlediği yönetsel uygulamalara ve oluşturulan kurum politikalarına aykırı hareket etmemek bu sorumlulukların başında gelmektedir. Oluşturulan yönetsel uygulama ve politikalar yukarıda bahsedildiği gibi alana ve çalışana uygun olduğunda çalışanlar için bu politikalara tabi olmak daha kolay olacaktır.

Çalışma yaşamı ve örgütsel ortamlar içinde birbirinden farklı insanlar bir arada çalışmak zorundadırlar. İnsanlar da yaratılışlarından dolayı birbirlerinden farklı özelliklere sahiplerdir. Farklı fiziksel, zihinsel ve kişilik özelliklerine sahip kişiler örgüt ikliminde bir araya geldiklerinde bir kaos meydana getirmektedir. Bu kaosu ya da gerilimi dengede tutabilmek için yönetsel uygulamalar ve politikalara ihtiyaç vardır. Çalışanların bu politika ve uygulamalar neticesinde birlikte kolaylıkla çalışabilmeleri sağlanmaktadır.

\section{YÖNTEM BILLIM VE MODEL}

Yapılan araştırma, nicel bir çalışma olup "keşfedici - tanımlayıcı araştırmalar" başlığı altında değerlendirilmektedir. Bu başlık altında değerlendirilmesinin nedeni, belirlenmiş bir ana kütle içerisinde örneklemin tesadüfi olarak seçilmiş olmasıdır. Yapılan anket uygulaması yöntemi ile örneklem üzerinden bilgi toplanmıştır. Aynı zamanda bu araştırma, "tanımlayıcı ve kesitsel araştırma" kapsamında da değerlendirilir.

Araştırmada yararlanılan ilk ölçek; katılımcıların farklılıkların yönetimine ilişkin algılarını ölçmek üzere Balay ve Sağlam (2004) tarafından geliştirilen 30 maddeden oluşan “Farklılıkların Yönetimi Ölçeği” kullanılmıştır (Balay ve Sağlam, 2004: 32-46). 
Yararlanılan ikinci ölçek ise Kwestionariusz Samoopisu'nun maddelerini Alman bir konuşmacı tarafından Almanca'ya aktarılan ve maneviyatın çeşitli yönlerini yansıtan diğer maddelerle desteklenerek manevi değerler kavramınının ölçümünde kullanılan "Manevi Değerler Ölçeği”' kullanılmıştır (Hardt vd. 2012: 116-122).

\subsection{Manevi Değerler, Farklılıklar Yönetimi ve Araştırma Uygulaması}

Araştırmanın ana kütlesi hizmet sektörü içerisinden belirlenmiştir. Çalışma bir vaka araştırması niteliğinde olduğundan Gaziantep ilindeki "GASKI'" (Gaziantep Su ve Kanalizasyon İdaresi) idari kadrosu temel alınmıştır. Kurum içerisinde görev alan kişilerin kimliklerinin araştırma kapsamı içerisinde gizli tutulmuş ve kurumun kimliğinin açıklanmasında herhangi bir sakınca görülmemiştir. Öz bildirim yöntemiyle doldurulan anket formlarında çalışmaya destek olan katılımcılardan formlar tek tek kontrol edilip araştırmacı tarafından teslim alınmıştır.

\section{2. Ölçüm Araçları}

Araştırmada anket yöntemi kullanılmıştır. Elde edilen verilere bu anketlere verilen cevaplar sonucunda ulaşılmıştır. Kullanılan anket formu iki bölümden oluşmaktadır. İlk bölümde katılımcıların demografik özelliklerini ölçmeye yönelik sorular yönetilmiştir. Bu kapsamda katılımcıların yaş, cinsiyet, statü, yönetici kademesi, çalışma kıdemi ve eğitim düzeyi bilgilerine ulaşılmıştır. İkinci bölümde katılımcıların farklılıklar yönetimi algılarını ölçmek üzere "Farklılıklar Yönetimi Ölçeği" ve katılımcıların manevi değerlerini ölçmek üzere “Manevi Değerler Ölçeği”” kullanılmıştır.

Araştırmada yararlanılan ilk ölçek; katılımcıların farklılıkların yönetimine ilişkin algılarını ölçmek üzere Balay ve Sağlam (2004) tarafından geliştirilen 30 maddeden oluşan “Farklılıkların Yönetimi Ölçeği”” kullanılmıştır (Balay ve Sağlam, 2004, ss. 32-46). Araştırmaya katılan bireylerin verilen ifadelere ilişkin tepkilerini belirlemek için olup ölçek 26 maddeden oluşmaktadır. Ölçeğin kullanıldığı çeşitli çalışmalarda alt boyutlara ilişkin güvenirlik 0,87 ile 0,97 (İnce vd. 2015, s. 303) ve 0,89 ile 0,93 (Ergül ve Kurtulmuş, 2014: 308) bulunmuştur. Dolayısıyla hem ölçeğin hem de alt boyutların oldukça güvenilir olduğunu ileri sürmek mümkündür. Ölçeğin yapı geçerliği Hutcheson ve Sofronio tarafından AFA ile incelenmiştir. AFA yapılmadan önce veri setinin faktör analizi için uygun olup olmadığını belirlemek amacıyla örneklem sayısının yeterliliğine ve Kaiser-Meyer-Oklin'in (KMO) ve Barlett Küresellik (BS) testlerine bakılmıştır. Yapılan analiz sonucu KMO değeri 0,94 ve Barlett Sphericity testi değeri 5611,812 (df: 351 p.000) olarak tespit edilmiştir. KMO değeri 0,70 ile 0,80 ise örneklem yeterliği iyi, 0,80 ile 0,90 arası ise çok iyi ve 0,90'dan yüksek ise mükemmel olduğu belirtilmektedir (Ergül ve Kurtulmuş, 2014, s. 302). Farklılıklar Yönetimi ölçeği Likert tipi bir ölçek olup bireysel tutum ve davranışlar, örgütsel değerler ve normalar, yönetsel uygulamalar ve politkalar olmak üzere 3 faktörden oluşmaktadır.

Yararlanılan ikinci ölçek ise Kwestionariusz Samoopisu'nun maddelerini Alman bir konuşmacı tarafından Almanca'ya aktarılan ve maneviyatın çeşitli yönlerini yansıtan diğer maddelerle desteklenerek manevi değerler kavramınının ölçümünde kullanılan "Manevi Değerler Ölçeği" kullanılmıştır (Hardt vd. 2012: 116-122). Geliştirilen madde havuzunda Allah inancı, Anlamlılık, Düşüncelilik ve Güvende olma hissi olmak üzere dört boyutu içermektedir. $\mathrm{Bu}$ çalışmada Allah inancı boyutu dışında bütün boyutlar kullanılmıştır. Araştırmada 
kullanılan ölçek bu ölçekten yola çıkarak çeviri ve uyarlamanın tamamen araştırmacı tarafından yapılmıştır. Ölçekteki maddeler araştırmacı tarafından çalışma kapsamında geliştirilmiştir. Manevi Değerler ölçeği beşli Likert ölçek olup anlamlılık, düşücelilik ve güvende olma hissi olmak üzere üç faktörden oluşmaktadır.

Kırk kişi üzerinde uygulanan pilot analiz çalışması sonrasında araştırmada toplam 41 madde yer alırken Farklılıklar Yönetimi ölçeğinden 12, Manevi Değerler ölçeğinden 5 madde çıkarılarak toplam 17 madde dışarıda bırakılmıştır.

\subsection{Araştırmanın Modeli ve Hipotezler}

Araştırmada bir tahmin değişkeninden yararlanılmıştır ve bu "Manevi Değerler" Ölçeği değişkenidir. Araştırmanın sonuç değişkeni "Farklılıkların Yönetimi” olarak belirlenmiştir.

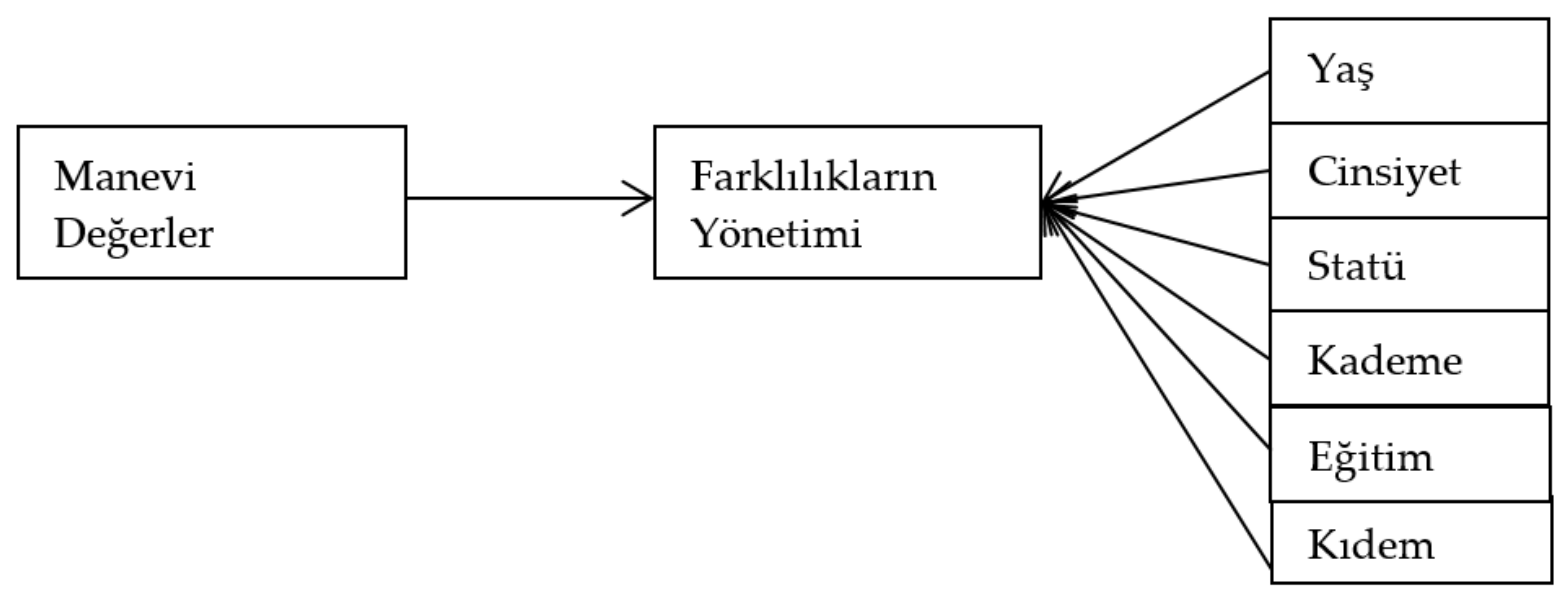

Şekil 1. Araştırmanın Modeli ve Hipotezler

\section{BULGULAR}

\subsection{Tanımlayıcı İstatistikler}

Araştırmaya katılanların \%35,9’u (61) kadın, \%64,1'i (109) erkeklerden oluşmaktadır. Bu bulgular doğrultusunda araştırmaya katılanların çoğunluğunun erkeklerden oluştuğu söylenebilir. Katılımcıların \%36,4'inin (62) 18-30 yaş grubunda, \%42,4'ünün (72) 31-40 yaş grubunda, \%21,2'sinin de (36) 41 yaş ve üzerinde olduğu görülmektedir. Bu bulgular doğrultusunda, ankete katılanların büyük bir çoğunluğunun 31-40 yaş grubunda olduğu anlaşılmaktadır. Eğitim durumu değişkenine göre katılımcıların \%19,5'ünün (33) lise ve altı öğrenim düzeyine, \%72,9'unun (124) önlisans ve lisans seviyesinde öğrenim düzeyine sahip olduğu, \%7,6'sının (13) ise lisansüstü öğrenim düzeyine sahip olduğu görülmektedir. Katılımcıların \%80'inin (136) yönetsel bir unvana sahip olmadığı, \%20'sinin (34) ise yönetici olduğu belirlenmiştir. Çalışma süresi değişkeni incelendiğinde, işletmede çalışanların \%64,7'sinin (110) 0-7 yıl arası, \%35,3'ünün (60) 8 yıl ve üzeri çalışma deneyimine sahip olduğu görülmektedir. 


\subsection{Güvenilirlik ve Geçerlilik Analizleri}

Anketlerin veri analizini yapabilmek için IBM SPSS Statistics 23.0 programına başvurulmuştur. Ölçeklerin faktör yapısını belirleyebilmek için Factor 10.5.03 programı kullanılmıştır. Doğrulayıcı Faktör Analizi için IBM'in AMOS modülünden yararlanılmıştır.

\subsubsection{Farklılıkların Yönetimi Ölçeğinin Güvenilirlik ve Geçerlilik Analizi}

Farklılıklar Yönetimi Ölçeği'nin genel güvenilirlik analizleri sonucunda Cronbach alfa değeri 0,91 olduğu görülmüştür. Farklılıklar Yönetimi Ölçeği'nin alt boyutları olan Bireysel Tutum ve Davranışlar boyutunun Cronbach alfa kat sayısı 0,51, Örgütsel Değerler ve Normlar boyutunun Cronbach alfa değeri 0,83, Yönetsel Uygulamalar ve Politikalar boyutunun Cronbach alfa katsayısı 0,93 olduğu sonucuna varılmıştır. Alfa katsayı değeri ölçeğin yüksek düzeyde güvenilir olduğuna işaret ettiğinden Farklılıklar Yönetimi Ölçeği güvenilir bulunmuştur.

Yapısal geçerlilik analizleri sonucunda benzeşme geçerliliği kapsamında; Farklılıklar Yönetimi için bileşik güvenilirlik değerleri de hesaplanmıştır. Bu açıdan değerlendirildiğinde, ölçeğe ait boyutlardan Bireysel Tutum ve Davranışlar boyutunun BG değeri 0,93; Örgütsel Değerler ve Normlar boyutunun BG değeri 0,97; Yönetsel Uygulamalar ve Politikalar boyutunun BG değeri ise 0,98 olarak bulunmuştur. Her üç boyut için de bileşik güvenilirlik katsayısı kriter değer olarak kabul edilmiş olup 0,70'in üzerinde olan değerler ile benzeşme geçerliliğinin sağlandığı görülmüştür.

Yapısal geçerlilik analizleri sonucunda benzeşme geçerliliği kapsamında; Farklılıklar Yönetimi için bileşik güvenilirlik değerleri de hesaplanmıştır. Bu açıdan değerlendirildiğinde, ölçeğe ait boyutlardan Bireysel Tutum ve Davranışlar boyutunun BG değeri 0,93; Örgütsel Değerler ve Normlar boyutunun BG değeri 0,97; Yönetsel Uygulamalar ve Politikalar boyutunun BG değeri ise 0,98 olarak bulunmuştur. Her üç boyut için de bileşik güvenilirlik katsayısı kriter değer olarak kabul edilmiş olup 0,70'in üzerinde olan değerler ile benzeşme geçerliliğinin sağlandığı görülmüştür.

\subsubsection{Manevi Değerler Ölçeğinin Güvenilirlik ve Geçerlilik Analizi}

Manevi Değerler Ölçeği'nin genel güvenilirlik analizleri sonucunda Cronbach alfa değerinin 0,83 olduğu görülmüştür. Manevi Değerler Ölçeği'nin alt boyutları olan Anlamlılık Cronbach alfa katsayısının 0,56, Düşüncelilik Cronbach alfa katsayısının 0,73, Güvende Olma Hissi Cronbach alfa katsayısının ise 0,73 olduğu sonucuna varılmıştır. Yapılan analizler ölçeğin yüksek güvenilirliğe sahip olduğunu göstermiştir.

Yapısal geçerlilik analizleri kapsamında; Manevi Değerler Ölçeği'nin alt boyutları olan Anlamlılık benzeşme geçerliliğinin 0,95, Düşüncelilik benzeşme geçerliliğinin 0,97, Güvende Olma Hissi benzeşme geçerliliğinin ise 0,96 olduğu sonucuna varılmıştır.

Manevi Değerler Ölçeği'nin Ki Kare Değerinin 2,56, KUI'nin 0,89, UII'nin 0,92, DUII'nin 0,86, YHOKK'nin 0,09 olduğu tespit edilmiştir.

\subsection{Hipotez Testi Sonuçları}

Manevi Değerler değişkeni (bağımsız değişkeni) ile Farklılıklar Yönetimi sonuç değişkeni (bağımlı değişkeni) arasındaki ilişkiler basit doğrusal regresyon analizi ile test edilmiştir. 
Amaç, sonuç değişkeninin tahmin değişkeni ile yordanıp yordanamayacağını belirlemektir. Regresyon analizini uygulamadan önce testin ön koşullarını karşılama durumu incelenmiştir. $\mathrm{Bu}$ doğrultuda, bağımlı ve bağımsız değişkenler arasında; doğrusallık, hataların normal dağılma özelliği, hataların bağımsız olması, hataların varyanslarının eşit olması ön koşulları incelenmiştir. Regresyon analizi sonuçları ve güven aralığı değerlerine yer verilmiştir.

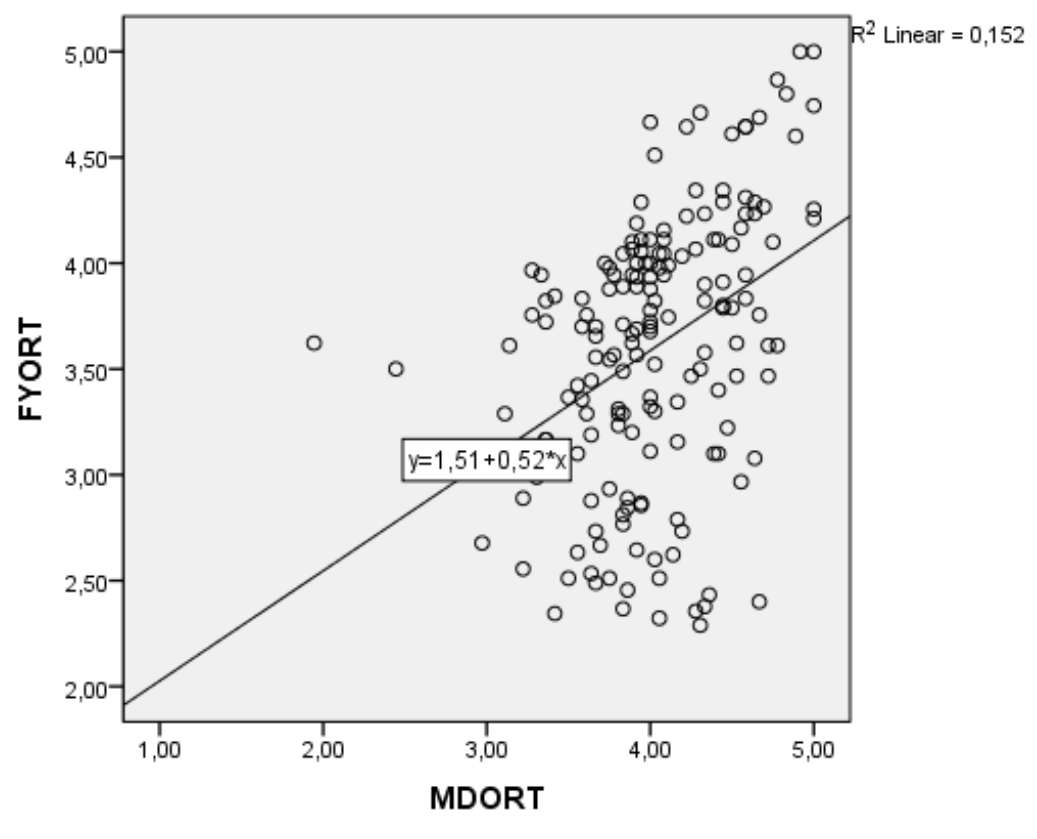

Şekil 2. Manevi değerler ve farklılıkların yönetimi ilişkisi serpilme grafiği.

Yapılan analiz çalışması sonrasında alternatif hipotezin $\left(\mathrm{H}_{1}\right)$ manevi değerler ile farklılıklar yönetimi arasında anlamlı bir ilişki olduğu sonucuna varılmıştır. İkinci modeller grubunda yer alan demografik değişkenlerle farklılıklar yönetimi arasında cinsiyet ve eğitim ile anlamlı ilişki olduğu; yaş, statü, yönetici kademesi, çalışma kıdemi ile anlamlı ilişki olmadığ sonucuna ulaşılmıştır.

Katılımcıların Manevi Değerler ölçeğinde yaptıkları işaretlemelerin Farklılıklar Yönetimini anlamlı bir şekilde tahmin etme imkânı sağlayıp sağlamadığını belirlemek için doğrusal regresyon analizi yapılmıştır. Tahmin değişkeninin varyansın 0,152 'sini açıkladığ 1 görülmüş ve manevi değerlerin farklılıklar yönetimini anlamlı ölçüde açıklama imkânı sağladığ $1\left(\mathrm{R}^{2}=\right.$ $0,152 ; \mathrm{F}=30,216 ; \mathrm{p}=0,000)$ tespit edilmiştir ( $\mathrm{p}=0,000 ; \mathrm{p}<0,001)$. Manevi değerler kavramı Farklılıklar yönetiminin 0,152 $\left(\mathrm{R}^{2}=0,152\right)$ oranında açıklamaktadır. İki kavramsal yapı arasındaki ilişkinin anlamlı bulunmasıyla araştırmanın temel hipotezi doğrulanmıştır. Diğer bir deyişle, işletmede çalışanların manevi değerlerdeki artış çalışanların farklılıklar yönetimi algısını olumlu yönde arttıracaktır. Sonuç olarak sıfır hipotezi reddedilmesinde başarı sağlanmış ve alternatif hipotez $\left(\mathrm{H}_{1}\right)$ kabul edilmiştir.

ANOVA tablosu bulguları incelendiğinde, anlamlılık değerinin $(\mathrm{p}=0,455)$ olduğu görülür. Anlamlılık değeri 0,05 'ten ( $p>0,05)$ büyük olduğundan 'yaş grupları arasında anlamlı farklılık yoktur' sonucuna varılmıştır. Bu doğrultuda, H0 hipotezi reddedilmesinde başarı sağlanamamış ve alternatif hipotez reddedilmiştir. 
$T$ testi tablosu bulguları incelendiğinde, anlamlılık değerinin $(p=0,010)$ olduğu görülür. Anlamlılık değeri 0,05'ten $(p<0,05)$ küçük olduğundan 'cinsiyet grupları karşılaştırıldığında farklılıklar yönetimi puanları arasında anlamlı farklılık' olduğu sonucu varılmıştır. Bu doğrultuda, H0 hipotezi reddedilmesinde başarı sağlanarak alternatif hipotez kabul edilmiştir.

Tablo 1. İkinci Hipotez İçin T Testi Analizi

\begin{tabular}{ccccccc}
\hline & $\mathrm{N}$ & Ortalama & Standart Sapma & $\mathrm{t}$ & $\mathrm{df}$ & \\
\hline Kadın & 61 & 4,07 & 0,43 &, 895 & 168 &, 372 \\
Erkek & 109 & 4,00 & 0,51 & & & \\
Toplam & 170 & & & & & \\
\hline
\end{tabular}

T testi tablosu bulguları incelendiğinde, anlamlılık değerinin $(p=0,578)$ olduğu görülür. 'statü grupları arasında anlamlı farklılık yoktur' sonucu varılmıştır. Bu doğrultuda, $\mathrm{H}_{0}$ hipotezi reddedilmesinde başarı sağlamış ve alternatif hipotez reddedilmiştir.

Tablo 2. Üçüncü Hipotez İçin T Testi Analizi

\begin{tabular}{ccccccc}
\hline & $\mathrm{N}$ & Ortalama & Standart Sapma & $\mathrm{t}$ & $\mathrm{df}$ & , \\
\hline Yönetici & 34 & 3,99 & 0,35 & 0,558 & 168 &, 578 \\
Yönetici Olmayan & 136 & 4,04 & 0,51 & & & \\
Toplam & 170 & & & & & \\
\hline
\end{tabular}

ANOVA tablosu bulguları incelendiğinde, anlamlılık değerinin $(p=0,253)$ olduğu görülür. 'yönetici kademe grupları arasında anlamlı farklılık yoktur' sonucu varılmıştır. Bu doğrultuda, $\mathrm{H}_{0}$ hipotezi reddedilmesinde başarı sağlanmış ve alternatif hipotez reddedilmiştir.

Tablo 3. Dördüncü Hipotez İçin Anova Analizi

\begin{tabular}{cccccc}
\hline \hline & Kareler toplamı & Serbestlik derecesi & Kareler toplamı & F & Anlamlılık \\
\hline İki grup arasında & 1,677 & 3 &, 559 & 1,374 & $\mathbf{2 5 3}$ \\
Gruplar içinde & 67,550 & 166 &, 407 & & \\
Toplam & 69,227 & 169 & & & \\
\hline
\end{tabular}

ANOVA tablosu bulguları incelendiğinde, anlamlılık değerinin $(\mathrm{p}=0,623)$ olduğu belirlenmiş ve 'çalışma kıdemi grupları arasında anlamlı farklılık yoktur' sonucu varılmıştır. Bu doğrultuda, $\mathrm{H}_{0}$ hipotezi reddedilmesinde başarı sağlanmış ve alternatif hipotez reddedilmiştir.

Tablo 4. Beşinci Hipotez İçin Anova Analizi

\begin{tabular}{cccccc}
\hline \hline & Kareler toplamı & $\begin{array}{c}\text { Serbestlik } \\
\text { derecesi }\end{array}$ & Kareler toplamı & F & Anlamlılık \\
\hline İki grup arasında &, 391 & 2 &, 196 &, 474 &, 623 \\
Gruplar içinde & 68,836 & 167 &, 412 & & \\
Toplam & 69,227 & 169 & & & \\
\hline
\end{tabular}


ANOVA tablosu bulguları incelendiğinde, anlamlılık değerinin $(\mathrm{p}=0,007)$ olduğu görülür. Anlamlılık değeri 0,05 'ten $(p<0,05)$ küçük olduğundan ‘eğitim grupları karşılaştırıldığında farklılıklar yönetimi puanları arasında anlamlı farklılık' olduğu sonucu varılmıştır. Bu doğrultuda, $\mathrm{H}_{0}$ hipotezi reddedilmesinde başarı sağlanarak alternatif hipotez kabul edilmiştir.

Tablo 5. Altıncı Hipotez İçin Anova Analizi

\begin{tabular}{cccccc}
\hline \hline & Kareler toplamı & $\begin{array}{c}\text { Serbestlik } \\
\text { derecesi }\end{array}$ & Kareler toplamı & F & Anlamlılık \\
\hline İki grup arasında & 4,042 & 2 & 2,021 & 5,178 &, 007 \\
Gruplar içinde & 65,185 & 167 &, 390 & & \\
Toplam & 69,227 & 169 & & & \\
\hline
\end{tabular}

\section{SONUÇ VE ÖNERILLER}

İnsanlar doğası gereği farklılıklara sahiptir. Bu farklılıklar sahip oldukları manevi değerlerde de görülmektedir. Farklı manevi değerlere sahip olan insanların farklılıkları yönetme konusundaki yaklaşımları yapılmış olan bu çalışmada detaylı bir şekilde incelenmiştir. Çalışma hayatında örgüt içerisindeki farklı çalışanların birlikte çalışma zorunlulukları göz önüne alındığında çatışmaları ve gerginlikleri dengede tutmak için manevi değerlerin etkileri bu çalışmada incelenmiştir. Manevi değerlerin farklılıkların yönetimi üzerindeki etkisinin temel alındığ 1 bu çalışmada demografik değişkenlerin (yaş, cinsiyet, eğitim, çalışma kademesi, kıdem) de farklılıkların yönetimi üzerindeki etkilerine yer verilmiştir. Bu çalışmada manevi değerler ve demografik değişkenlerden yola çıkarak farklılıkların yönetimi algılarının anlamlı bir farklılık gösterip göstermediği konusu incelenmiştir.

Çalışmada ön analizler yapıldıktan sonra bir takım bulgular edinilmiştir. Farklılıklar Yönetimi Ölçeğinin puanları ile Manevi Değerler Ölçeğinin puanları arasındaki ilişkiler basit doğrusal regresyon analiziyle incelenmiş olup çalışmanın temel hipotezi doğrulanmıştır. Diğer bir deyişle manevi değerleri daha güçlü olan çalışanların farklılıkları yönetme konusundaki hassasiyet ve algısı manevi değerleri güçlü olmayan çalışanlara göre daha yüksek bulunmuştur. Demografik değişkenler ile farklılıklar yönetimi arasındaki ilişkiler incelendiğinde yaş, statü, yönetici kademesi ile farklılıklar yönetimi arasında anlamlı bir fark bulunmamıştır. Buna karşılık cinsiyet ve eğitim ile farklılıklar yönetimi arasında anlamlı farklar bulunmuştur.

$\mathrm{Bu}$ çalışma sonucunda ulaşılan bilgi ve bulgular genelleme yapabilmek için yetersizdir. Ancak söz konusu çalışmanın diğer çalışmalar için farklılıkların yönetimi ve manevi değerler kavramsal yapılarını zenginleştirdiğini ileri sürmek mümkündür.

Bu çalışma sadece hizmet sektöründe bir vaka çalışması olarak yapılmıştır. Konuyla alakalı yapılacak daha kapsamlı çalışmalar neticesinde genelleme yapılabilecek sonuçlar elde edilebilir. Yapılması planlanacak bu konuyla alakalı çalışmalarda bu husus dikkate alınmalıdır. Son yıllarda konu ile ilgili geliştirilen araştırmalardaki genel görünüm, farklılıkları yönetmeninin kurumların altyapısını zenginleştirme yönündedir. Bu nedenle çeşitli disiplinlerden destek almak, farklı kavramsal yapılarla birlikte konuyu değerlendirmek gerekmektedir. Farklı disiplinlerle birlikte yapılan bilimsel çalışmalar sonucunda süreç içerisinde farklılıkların yönetiminin etki alanlarını saptanması sağlanacaktır. Bu sebeple bir 
öneri olarak farklılıklar yönetiminin diğer kesişim alanlarıyla beraber çalışması gerektiği olacaktır.

Son olarak farklılıklara saygı duyulması gerekir ve farklılıkların hafızalarda yerleşmiş kalıplarından kurtulup manevi değerlerle yaklaşım gösterilen çalışmalar yapılması, konunun üzerine yapılacak araştırmalar açısından çok daha sağlıklı olacaktır.

\section{KAYNAKÇA}

Ayverdi, İ. (2005). Misalli Büyük Türkçe Sözlük. İstanbul: Kubbealtı.

Balay, R., \& Sağlam, M. (2004). Eğitimde Farklılıkların Yönetimi Ölçeğinin Uygulanabilirliği. Süleyman Demirel Üniversitesi Burdur Ĕ̆itim Fakültesi Dergisi, 5(8), 32-46.

Bassett-Jones, N., Brown, R. B., \& Cornelius, N. (2007). Delivering Effective Diversity Management Through Effective Structures. Systems Research and Behavioral Science, 24(1), 59-67.

Bütüner, O. (2011). İşletmelerde Örgüt Kültürü ve Örgütsel Değerlerin İş Sağlı̆̆1 ve Güvenliği Uygulamalarına Etkisi Üzerine Bir Araştırma . Dokuz Eylül Üniversitesi Sosyal Bilimler Enstitüsü. İzmir, İzmir, Türkiye.

Çeçen, A. R. (2008). Üniversite Öğrencilerinde Yaşam Doyumunu Yordamada Bireysel Bütünlük (Tutarlılık) Duygusu, Aile Bütünlük Duygusu ve Benlik Saygısı. Journal of Theory and Practice in Education, 4(1), 19-30.

Demirkapı, E. Ş. (2013). Çocukluk Çağı Travmalarının Duygu Düzenleme ve Kimlik Gelişimine Etkisi ve Bunların Psikopatolojiler ile İlişkisi. Adnan Menderes Üniversitesi Sağlık Bilimleri Enstitüsü. Aydın, Aydın, Türkiye.

Deniz, M. E., Arslan, C., Özyeşil, Z., \& İzmirli, M. (2012). Öz-Anlayış, Yaşam Doyumu, Negatif ve Pozitif Duygu, Türk ve Diğer Ülke Üniversite Öğrencileri Arasında Bir Karşılaştırma. Mehmet Akif Ersoy Üniversitesi Ĕ̆itim Fakültesi Dergisi(23), 428-446.

Dilmaç, B., Bozgeyikli, H., \& Çıkılı, Y. (2008). Öğretmen Algılarının Değer Algılarının Farklı Değişkenler Açısından İncelenmesi. Değerler Ĕ̆itimi Dergisi, 6(16), 69-91.

Direk, D. Y. (2006). Sosyo-Kültürel Yapının Konut Oluşumuna Etkisi: Diyarbakır Örneği. Elektronik Sosyal Bilimler Dergisi, 5(16), 105-113.

Erdem, M., \& Kesgin, B. (2017). Manevi Destek Uygulayıcılarının Manevi Destek Hizmetlerine İlişkin Görüşleri. Yalova Sosyal Bilimler Dergisi(15), 124-140.

Ergül, H. F., \& Kurtulmuş, M. (2014). Farklılıklar Yönetimi Ölçeğinin Geçerlilik, Güvenilirlik Çalışması. Dicle Üniversitesi Ziya Gökalp eğitim Fakültesi Dergisi(22), 298-312.

Ersoy, E. G., \& Köşger, F. (2016). Empati:Tanımı ve Önemi. Osmangazi Tıp Dergisi, 38.

Gürel, A. (2006). İşletmelerde Personel Seçme ve Yerleştirmede Yetkinlik Yönetimi: Bir Araştırma. Pamukkale Üniversitesi Sosyal Bilimler Enstitüsü. Denizli, Denizli, Türkiye: Pamukkale Üniversitesi. 
Hardt, J., Schultz, S., Xander, C., Becker, G., \& Dragan, M. (2012). The Spirituality Questionnaire: Core Dimensions of Spirituality. PSYCH Journal, 3(1), 116-122.

Horozcu, Ü. (2010). Tecrubi Araştırmalar Işığında Dindarlık ve Maneviyat ile Ruhsal ve Bedensel Sağlık Arasındaki İlişki. Milel ve Nihal İnanç, Kültür ve Mitoloji Araştırmaları Dergisi, 7(1), 209-236.

İnce, M., Gül, H., Candan, H., \& Çakıcı, A. B. (2015). Örgütlerde Sınırlandırıcı Yada Sürükleyici Güç Olarak Farklılıkların Yönetimi. Sosyal Bilimler Elektronik Dergisi(12), 292-321.

Kağıtçıbaşı, Ç. (1988). İnsan ve İnsanlar. İstanbul: Evrim Basım Yayım Dağıtım.

Kahveci, Y. D. (2009). Lafız Mana İlişkisi Bağlamında İşaretin Delaleti. İslam Hukuku Araştırmaları Dergisi(14), 185-202.

Kılıç, Y. K. (2010). Bireysel ve Örgütsel Değerler Arasındaki Uyumun Çalışanların İş Davranışlarına Etkileri Üzerine Ampirik Bir Çalışma. Ç.Ü. Sosyal Bilimler Enstitüsü Dergisi, 19(1), 20-35.

Kimter, Ç. Y. (2013). Din ve Maneviyatı Kavramlaştırma: Birleşme ve Ayrılma Noktaları. Çanakkale On Sekiz Mart Üniversitesi İlahiyat Fakültesi Dergisi(3), 85-118.

Memduhoğlu, H. B. (2011). Liselerde Farklılıkların Yönetimi: Bireysel Tutumlar, Örgütsel Değerler ve Yönetsel Politikalar. Mersin Üniversitesi Ĕ̆itim Fakültesi Dergisi, 7(2), 37-53.

Okat, B. (2010). Örgütlerde Farklılıkların Yönetimi Ve Farklılık İklimine Kuramsal Bir Yaklaşım. İzmir, Türkiye.

Özan, D. D., \& Polat, A. G. (2013). İlköğretim Öğretmenlerinin Farklılıkların Yönetimine Yönelik Algıları (Muş İli Örneği).e-International Journal of Educational Research, 4(1), 5577.

Püsküllüoğlu, A. (2004). Arkadaş Türkçe Sözlük. Ankara: Arkadaş Yayınları.

Rio, C. D., \& White, L. J. (2016). Maneviyatı Dindarlıktan Ayırmak: Hilomorfik Bir Bakış Açısı. Tasavouf İlmi ve Akademik Araştırma Dergisi, 73-113.

Sardarov, E. (2012). Tutum ve Davranış. Dokuz Eylül Üniversitesi. İzmir, İzmir, Türkiye.

Sürgevil, O., \& Budak, G. (2008). İşletmelerin Farklılıkların Yönetimi Anlayışına Yaklaşım Tarzlarının Saptanmasına Yönelik Bir Araştırma. Dokuz Eylül Üniversitesi Sosyal Bilimler Enstitüsü Dergisi, 10(4), 65-96.

Tarhan, N. (2012, 12 28). Nevzat Tarhan. Kasım 10, 2018 tarihinde www.nevzattarhan.com: https://www.nevzattarhan.com/guven.html adresinden alındı

Topsakal, H. R., \& Çetin, İ. (1996). Örnekleriyle Türkçe Sözlük. Ankara: MEB Yayınları.

Tozkoparan, G. (2013). Beş Faktör Kişilik Özelliklerinin Çatışma Yönetim Tarzlarına Etkisi: Yöneticiler Üzerinde Bir Araştırma. Ekonomik ve Sosyal Araştırmalar Dergisi, 9(2), 189231.

Tozkoparan, G., \& Vatansever, Ç. (2011). Farklılıkların Yönetimi: İnsan Kaynakları Yöneticilerinin Farklılık Algısı Üzerine Bir Odak Grup Çalışması. Akdeniz İ.̇.B.F. Dergisi(21), 89-109. 
Türk Dil Kurumu. (2018, Ekim 20). 2018 tarihinde www.tdk.gov.tr: http://www.tdk.gov.tr/index.php?option=com_gts\&arama=gts\&guid=TDK.GTS.5bd4 a33ea29a56.89872863 adresinden alındı

Türk Dil Kитити. (2018, Ekim 20). 2018 tarihinde www.tdk.gov.tr: http://www.tdk.gov.tr/index.php?option=com_gts\&arama=gts\&guid=TDK.GTS.5bd4 a4cf306007.67012447 adresinden alınd 1

Türk Dil Kurumu. (2018, Kasım 10). Kasım 10, 2018 tarihinde www.tdk.gov.tr: http://www.tdk.gov.tr/index.php?option=com_gts\&arama=gts\&guid=TDK.GTS.5be73 49e767dc5.51646934 adresinden alındı

Vurgun, Y. D., \& Öztop, S. (2011). Yönetim ve Örgüt Kültüründe Değerlerin Önemi. Süleyman Demirel Üniversitesi İktisadi ve İdari Bilimler Fakültesi Dergisi, 16(3), 217-230.

Yetgin, S. (2016, Haziran). İşletmelerde Farklılıkların Yönetimi: Giresun İlinde Faaliyet Gösteren Tekstil İşletmeleri Üzerine Bir İnceleme. Mersin: Türkiye. 